\title{
咀嚼が食塊の咽頭進入に及ぼす影響
}

\author{
武田斉子*1 才藤 栄一*1 松尾浩一郎*1,*2 \\ 馬場 尊*1 藤井 航*1 Jeffery B PALMER*3
}

\section{Influence of Chewing on Food Transport and Swallowing}

\author{
Seiko Takeda, ${ }^{* 1}$ Eiichi Saitoh, ${ }^{* 1}$ Koichiro Matsuo, ${ }^{* 1, * 2}$ \\ Mikoto BaBA, ${ }^{* 1}$ Wataru FujII, ${ }^{* 1}$ Jeffery B PALMER ${ }^{* 3}$
}

\begin{abstract}
When normal subjects eat solid food, the bolus is formed in the oropharynx prior to swallowing. Bolus formation for liquids, however, is usually in the mouth. The purpose of this study was to determine whether the act of chewing alters the relationship between bolus position and swallow initiation. Ten healthy volunteers aged 29.2 44.1 years were imaged with videofluorography while consuming barium-mixed foods included 10 ml-liquid (LQD), 8 g-corned beef hash $(\mathrm{CBH}), 8 \mathrm{~g}$-cookie $(\mathrm{COK})$, and a mixture of 5 ml-liquid with $4 \mathrm{~g}-\mathrm{CBH}$ (MIX). They were instructed to chew and then swallow. For liquid, an additional recording was made with command swallow. Swallow onset was defined as the moment hyoid began its rapid elevation. The position of the leading edge of bolus at swallow onset and the duration of bolus transition were measured. The position of the leading edge of bolus was classified in Oral cavity (OC), Upper-oropharynx (UOP), Valleculae (VAL), or Hypopharynx (HYP). With LQD, the leading edge of bolus was in OC or UOP at time of swallow onset in $89.5 \%$ of swallows without chewing. In contrast, bolus entered VAL and HYP before swallow onset in $45 \%$ of swallows of LQD with chewing. For $\mathrm{CBH}$ and $\mathrm{COK}$, the leading edge of the bolus entered VAL before swallow onset in $55.0 \%$ and $50.0 \%$ of swallows, respectively. For MIX swallows, the leading edge reached VAL or lower before swallow onset in $100 \%$ of swallows. From these findings the act of chewing seemed to be a prime determinant of a manner of chew-swallow complex characterized by the existence of the stage II transport. And for observation of this phenomenon clinically, MIX chew-swallowing is the most suitable because of its high reliability. In chew-swallow of food including liquid properties (LQD and MIX), high frequency of bolus entering in HYP before swallow onset was observed. The food transport to hypopharynx seemed to be influenced by gravity. This finding was very important in consideration of aspiration mechanism of dysphagic patients especially with falsenegative results of videofluorographic study. High correlation was recognized in the chewing time and the oropharyngeal transport time, and hypopharyngeal transit time was long in LQD with chewing and MIX. Steadiness of hyoid bone movement time indicated that this parameter should be suitable for standardize of time measurement. The manner of chew-swallow complex was obviously different from that of command swallow. It seemed to be important clinically to assess chew-swallow complex additionally to the conventional videofluorography. (Jpn J Rehabil Med $2002 ; 39$ : 322-330)
\end{abstract}

2002 年 3 月 25 日受付, 2002 年 5 月 31 日受理

*1 藤田保健衛生大学医学部リハビリテーション医学講座/テ 470-1192 愛知県豊明市沓掛町田楽ヶ窪 1-98

Department of Rehabilitation Medicine, School of Medicine, Fujita Health University

*2 東京医科歯科大学大学院医歯学総合研究科老化制御学系専攻口腔老化制御学講座口腔老化制御学分野/ $\mathrm{T} 113-0034$ 東 京都文京区湯島 1-5-45

Gerodontology, Department of Gerodontology, Division of Gerontology and Gelodontology, Graduate School, Tokyo Medical and Dental University

${ }^{* 3}$ Department of Physical Medicine and Rehabilitation, Johns Hopkins University Medical School and Good Samaritan Hospital 
要 旨: 咀嚼嶼下の評価法の確立のため, 健常成人 10 名を対象として, 4 食物条件下で咀 嚼が嚥下反射開始前の食塊位置および嚥下時間経過に及ぼす影響を嬩下造影検査を用いて検討 した．液体命令嶼下に比し全咀嚼条件で食塊先端位置の中～下咽頭への到達率が高く，食塊進 入には咀嚼の存在が一義的に関与し，食物形態はそれを修飾する役割を担うと思われた．混合 咀緭条件では食塊は全例で嬩下前に中〜下咽頭へ到達しており，信頼性の高い負荷法といえ た．液体を含む咀嚼舆下では，下咽頭到達が高率で下咽頭通過時間も長く, 誤嬩防止の観点か ら興味深い所見であうた。咀嚼嚥下は命令嚥下とは別様式であり「食べる」機能の評価と位置 づけられた。(リ八医学 $2002 ; 39: 322-330$ )

Key words: 嬹下障害 (swallowing disorder), 咀嚼 (mastication), 食物形態 (food consistency)，ビデオ嚥下造影検査（videofluorography）

\section{はじめに}

嶼下障害の標準的検査としてビデオ嬩下造影検査 (Videofluorography：VF）が広く用いられている。 この検査により，誤嚥の同定，不顕性誤嶼の発見，効 果的な食物形態・体位・代償法の決定など治療に直結 する極めて具体的な所見を得ることができるからであ $ろ^{1,2)}$.

ところで，これまでVFにおける臙下動態の解析 は，主に 4 期モデル (four-stage sequence model) を基本概念において行われてきた。このモデルは命令 嚥下 (command swallow), すなわち, 液体や食塊 を口腔に含ませた後，「飲んでください」という命令 を合図に一息で飲み込む嚥下運動の観察から定義され たものであり，これは検査を効率的に行うための単純 化として広く受け入れられてきた 嶼下運動を口腔準備期, 口腔送り込み期, 咽頭期, 食 道期という 4 期のはっきりとした時間的連続過程とし て捉える考え方である。特に，嬩下反射の開始時期に ついては，食塊が口腔からの送り込みにより中咽頭へ 運ばれるとその直後に喉頭挙上を伴う咽頭期が続くと され，この考え方をもとに各期の開始や終了を定義 し，その延長や黇下反射の遅延を議論してきた。しか し，ゼリーなど模擬食品の摂食時には一息で飲み込む ことは少なく，4期モデルとは異なる曣下動態の存在 に気づかれるようになった。

Hiiemae と Palmer は咀嚼を要する固形物の嚥下 動態を解析し， 4 期モデルとは異なった概念を用いて 解釈する必要があることを示した ${ }^{4,5)}$ 。それがVFを 用いた一連の実験から提案されたプロセスモデル (Process model) である5). プロセスモデルは固形物 の咀嚼を含む嚥下動態を液体の命令嶼下と比較した初 めてのモデルであり, 咀嚼嚥下（chew-swallow complex）時には，咀嚼により與下可能なまでに粉砕され
た食物が舌による能動的輸送によって中咽頭に送り込 まれ，そこで食塊としてまとめられることが特徴とな る．彼らは，この咀嚼と同期しておこる舌による食物 の能動的輸送を Stage II transport と定義した。これ までの液体の命令嚥下の解析では，臙下反射開始前に 食塊が口峡を越えて咽頭に達する例は嬩下反射の遅れ などの異常があると考えられていた が，咀嚼条件下 では口峡あるいは喉頭蓋谷で食塊形成の行われること が通常であることが理解され，4期モデルの汎用に再 考を促すこととなった。

我々は, 咀嚼を伴う嗌下が日常行われる通常の食事 行為であることから, その評価の重要性を考え, 臨床 的評価法として標準化するために，未だ明らかとなっ ていない以下の点を解明する目的で検討を行った。す なわち，1）プロセスモデルに特徴的な Stage II transport をもたらす要因として重要なのは，咀嚼に 伴って起こる舌の動きか食物形態か，2） Stage II transport の発生頻度はどの程度で食物形態により恋 化するかどうか，3）咽頭内での食塊形成の場の広が りはどのようなもので食物形態により恋化するかどう か，4）咀嚼嚥下の場合, 嚥下各期の位相時間の構成 はどのようなものか.

健常者を対象に咀嚼嚥下の際の嶼下反射開始時の食 塊先端の深達度および鱑下反射開始のタイミングを計 測した。その際，固形物に加えて，液体および液体と 固形物の混合物を被検物として用いた。

\section{対象と方法}

\section{1. 対 象}

神経疾患や咽頭・喉頭疾患の既往がなく，摄食・嶼 下障害に関する愁訴のない健常成人 10 名（男性 6 名, 女性 4 名. 年齢 $29.2 \pm 4.1$ 歳）を対象とした。被験者 には実験の方法および使用する食品の説明のみ行い, Stage II transportに関する説明は行わなかった。透 
視室で楽な姿勢で椅子に座らせて VF を行い，VF 側 面像をデジタルビデオに記録した。被験物として, （1）50\%バリウム水溶液 $10 \mathrm{ml}$ (液体)，（2）バリウ ム含有コンビーフ $8 \mathrm{~g}$ (コンビーフ), (3) バリウム 塗布クッキー $8 \mathrm{~g}$ (クッキー), （4）50\%バリウム水 溶液 $5 \mathrm{ml}$ とバリウム含有コンビーフ $4 \mathrm{~g}$ の混合物 （混合）を用いた。固形の被験物の量は Hiiemae らの Process model の研究5) に準じて決定し, コンビーフ は Process model で用いられた chicken spread の類 似品として用いた。

\section{2. 嚥下条件の定義}

咀嚼嚥下では, 各被験物について「味わうように嚙 んで食べてください」と被験者に指示を与え, 自由咀 嚼させた後に生じる自由なタイミングでの䁩下を観察 した（以下，各々，液体咀嚼，コンビーフ，クッキ 一, 混合と表現)。液体においては命令曣下を追加し た（以下，液体命令)。命令瞐下の際には, 液体を口 腔前庭内にシリンジで注入した後,「飲んでください」 という指示によって飲み込ませた。

\section{3. 解析方法}

各条件で 2 試行ずつ記録した計 20 試行のビデオデ ータをスローモーションで再生し解析した，用いたビ デオタイマーは $1 / 100$ 秒，デジタルビデオテープは 30 フレーム/秒である.デー夕記録上の不備例を除外 し, 解析対象は, 液体命令では 19 試行, 混合では 18 試行となった.

嚥下に先だって舌骨が上前方への挙上を開始した時 点を嚥下反射開始時点と定義した。画像上における舌 骨の急速な移動を嚥下反射開始と判定し, その直前の 画像フレームにおける食塊先端の到達した部位を「曖 下反射開始時点の食塊先端位置（以下，食塊先端位 置)」とした。 また，それぞれの領域における食塊の 通過時間を計測した。

\section{1 食塊先端位置}

食塊先端位置は Palmer らの Process model ${ }^{5)}$ を一 部改変し, 以下のように分類した（図1).すなわち, a）口腔内（Oral cavity area, OC), b) 口腔咽頭上部 領域 (Upper oropharynx area, UOP)：VF 側面像で 硬口蓋と軟口蓋の境界を越え下顎下縁の線に達するま で，c）喉頭蓋谷領域 (Valleculae area, VAL)：下顎 下縁を越え喉頭蓋谷底に達するまで，d）下咽頭領域 (Hypopharynx area, HYP) : 喉頭蓋谷を越元食道入 口部に達するまで，とした。また，咽頭への深達度を

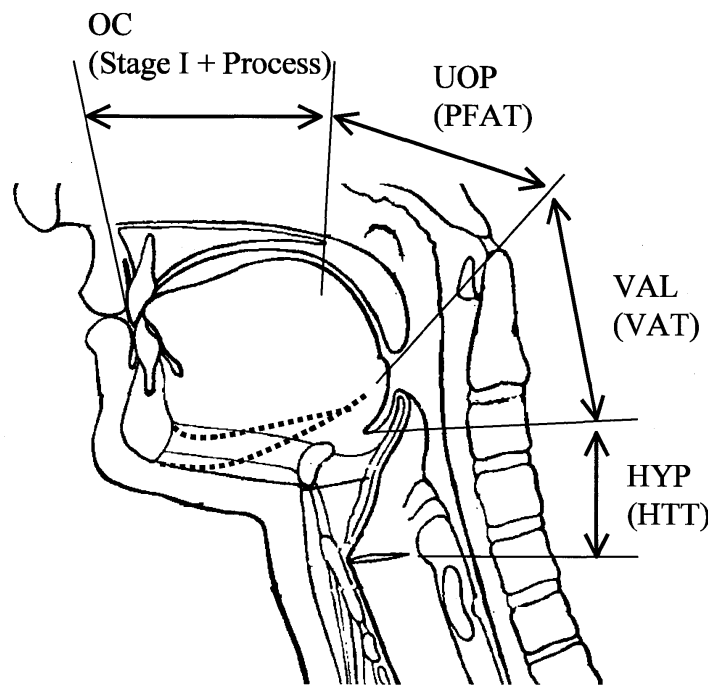

図 1 口腔・咽頭領域の区分

食塊先端位置を示すのに，図のように口腔・咽頭を区分し た.（）内に領域に対応した位相時間の定義を示した。

OC: Oral cavity area (口腔内), UOP: Upper oropharynx area（口腔咽頭上部領域), VAL: Valleculae area（喉 頭蓋谷領域), HYP: Hypopharynx area (下咽頭領域). Stage I + Process: (口腔内移送時間), PFAT: Postfaucial aggregation time (口腔咽頭上部領域通過時間), VAT: Valleculae aggregation time (喉頭蓋谷領域通過 時間), HTT: Hypopharyngeal transit time (下咽頭領 域通過時間).

口腔咽頭上部領域以降: UOP + VAL + HYP (UOP or more, 以下 UOP-om), 喉頭蓋谷領域以降: $\mathrm{VAL}+\mathrm{HYP}$ (VAL or more, 以下 VAL-om), HYP の 3 段階に分けて検討した.

\section{2 位相時間}

興下各位相は Palmer らに準拠し, 食塊が OC を通 過する時間 (口腔内移送時間) : Stage I+Process, UOP を通過する時間（口腔咽頭上部領域通過時間）:

Postfaucial aggregation time (PFAT), VAL を通 過する時間 (喉頭蓋谷領域通過時間) : Valleculae aggregation time (VAT), HYPを通過する時間 (下咽頭領域通過時間): Hypopharyngeal transit time（HTT）として, ビデオタイマーにより時間を 計測し, 各被験物における位相の差を検討した。

実験にあたって, 被験者には文章抽よび口頭で実験 の主旨と内容を十分に説明し同意を得た. 統計処理に は食塊先端の各領域への到達率の検討に Fisher's exact test を用い, 各被験物における嚥下位相時間の 差の検討に ANOVA を用いた。 
表 1 嚥下反射開始時の食塊先端の位置

\begin{tabular}{|c|c|c|c|c|c|}
\hline & $\begin{array}{c}\text { 液体 } \\
\text { 命令興下 }\end{array}$ & $\begin{array}{c}\text { 液体 } \\
\text { 咀嚼嬹下 }\end{array}$ & $\begin{array}{c}\text { コンビーフ } \\
\text { 咀嚼嬹下 }\end{array}$ & $\begin{array}{l}\text { クッキー } \\
\text { 咀嚼嬩下 }\end{array}$ & $\begin{array}{c}\text { 混合 } \\
\text { 咀嚼嬩下 }\end{array}$ \\
\hline 総数 & 19 & 20 & 20 & 20 & 18 \\
\hline $\mathrm{OC}$ & $12(63.2)$ & $9(45.0)$ & $3(15.0)$ & $2(10.0)$ & $0(0.0)$ \\
\hline UOP & $5(26.3)$ & $2(10.0)$ & $6(30.0)$ & $5(25.0)$ & $0(0.0)$ \\
\hline VAL & $2(10.5)$ & $4(20.0)$ & $11(55.0)$ & $10(50.0)$ & $5(27.8)$ \\
\hline HYP & $0(0.0)$ & $5(25.0)$ & $0(0.0)$ & $3(15.0)$ & $13(72.2)$ \\
\hline $\mathrm{UOP}$ or more & $7(38.6)$ & $11(55.0)$ & $17(85.0)$ & $18(90.0)$ & $18(100.0)$ \\
\hline VAL or more & $2(10.5)$ & $9(45.0)$ & $11(55.0)$ & $13(65.0)$ & $18(100.0)$ \\
\hline
\end{tabular}

ケース数 (\%). 液体命令では曣下開始前にはほとんどの例で食塊が口腔に保持されている

（63.2\%）が，液体咀嚼では中一下咽頭に食塊が達する率が高い（VAL or more：45.0\%).

特に混合では全例でVAL or more に達していた。 下咽頭到達率は液体咀嚼で $25.0 \%$, 混合

で $72.2 \%$ と, 液体を含む食品の咀嚼条件下で高率であった. OC：Oral cavity area（口腔

内), UOP : Upper oropharynx area（口腔咽頭上部領域), VAL: Valleculae area（喉頭 蓋谷領域), HYP: Hypopharynx area (下咽頭領域), UOP or more: UOP+VAL+ HYP (口腔咽頭上部領域以降), VAL or more: VAL + HYP (喉頭蓋谷領域以降).

表 2 食塊先端の深達度の検討（Fisher's exact test）

\begin{tabular}{|c|c|c|c|c|c|c|}
\hline 食塊先端位置 & $\begin{array}{l}\text { 液体命令 } \\
\text { 液体咀嚼 }\end{array}$ & $\begin{array}{l}\text { 液体命令 } \\
\text { コンビーフ }\end{array}$ & $\begin{array}{l}\text { 液体命令 } \\
\text { クッキー }\end{array}$ & $\begin{array}{c}\text { 液体命令 } \\
\text { 混合 }\end{array}$ & & \\
\hline UOP or more & 0.208 & 0.003 & 0.001 & $<0.001$ & & \\
\hline VAL or more & 0.019 & 0.004 & 0.001 & $<0.001$ & & \\
\hline HYP & 0.027 & 1.000 & 0.125 & $<0.001$ & & \\
\hline 食塊先端位置 & $\begin{array}{l}\text { 液体咀嚼 } \\
\text { コンビーフ }\end{array}$ & $\begin{array}{l}\text { 液体咀嚼 } \\
\text { クッキー }\end{array}$ & $\begin{array}{c}\text { 液体咀嚼 } \\
\text { 混合 }\end{array}$ & $\begin{array}{c}\text { コンビーフ } \\
\text { クッキー }\end{array}$ & $\begin{array}{c}\text { コンビーフ } \\
\text { 混合 }\end{array}$ & $\begin{array}{c}\text { クッキー } \\
\text { 混合 }\end{array}$ \\
\hline UOP or more & 0.041 & 0.016 & 0.001 & 0.500 & 0.135 & 0.270 \\
\hline VAL or more & 0.376 & 0.170 & $<0.001$ & 0.374 & 0.001 & 0.006 \\
\hline HYP & 0.024 & 0.347 & 0.004 & 0.115 & $<0.001$ & 0.001 \\
\hline
\end{tabular}

被験物の違い, 咀嚼の有無と各領域における嬹下反射開始直前の食塊到達率の差を検定した. 表 中は Fisher's exact test によるp 值を記した。液体では咀嚼の有無によりVAL or more, HYP で食塊到達率に差を認めた. 混合咀嚼は他被験物と比べ, すべての領域で食塊到達率に差を認め た $(p<0.05)$.

\section{結 果}

\section{1. 食塊先端位置の深達度の検討（表 1, 表 2)}

液体命令では，噁下反射開始前に食塊先端位置 は口腔内に存在する率が高く, OC $63.2 \%$, UOP $26.3 \%$, VAL $10.5 \%$, HYP $0 \%$ ，䜩下反射開始前 に食塊が下咽頭に達する例は 1 例も認めなかった。

液体咀嚼では，OC $45.0 \%$, UOP $10.0 \%$, VAL 20\%, HYP 25\%であり, 約半数で嶼下反射開始前に 食塊先端が喉頭蓋谷に達し,さらに $1 / 4$ 例で下咽頭に 達していた。

固形物における VAL, HYP への深達率は, コン

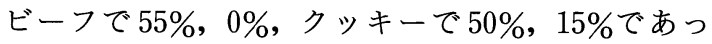
た.
混合では, VAL 27.8\%，HYP 72.2\%であり，全 例で嬩下反射開始前に食塊が喉頭蓋谷以降に達し, 特 に下咽頭に到達している率が高かった，図 2 に代表例 を示す．ビデオから各条件における䜩下反射開始直前 の画像を切り出して, 食塊先端位置を同定した。液体 咀嚼および混合では嶼下反射開始以前に食塊が下咽頭 に達しているのが明らかである。

表 2 に深達度の比較を示す. UOP-om については, 液体命令とコンビーフ,クッキー, 混合との間に有意 差を認めた。液体咀嚼とその他の咀嚼条件の間にも有 意差を認めた.コンビーフ,クッキー, 混合との間に は有意差を認めなかった。 なお，コンビーフとクッキ 一の間には，すべての条件で深達度に有意差を認めな かった。 
1. 液体命令: OCA

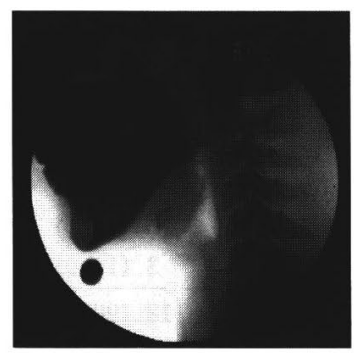

3. コンビーフ:VAL

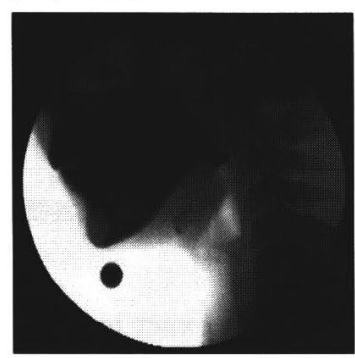

2. 液体咀獣: HYP

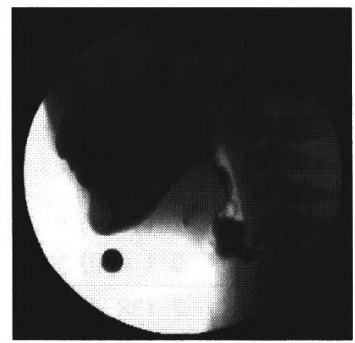

4. 混合:HYP

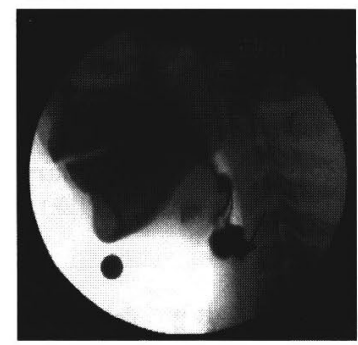

図 2 嬩下反射開始直前の食塊先端位置（31 歳, 女性）

嘸下反射門始を舌骨の上前方移動開始時と定義し，ビデオ画像で舌骨が上前方に急速に移動を開始する直 前のフレームから食塊先端の位置を同定した。液体咀嚼, 混合咀嚼で食塊先端が下咽頭に達している。 OC: Oral cavity area (口腔内), VAL: Valleculae area (喉頭蓋谷領域), HYP : Hypopharynx area (下咽頭領域)

表 3 鱘下位相時間

\begin{tabular}{|c|c|c|c|c|c|}
\hline & 液体命令 & 液体咀嚼 & コンビーフ & クッキー & 混合 \\
\hline Stage I + Process & $3.35(3.01)$ & $4.86(2.76)$ & $7.53(3.65)$ & $13.78(7.40)$ & $4.59(3.80)$ \\
\hline PFAT & $0.33(0.24)$ & $1.72(2.34)$ & $3.34 \quad(3.49)$ & $2.62(2.65)$ & $1.37(1.69)$ \\
\hline VAT & $0.15(0.35)$ & $1.17(1.81)$ & $0.63(0.70)$ & $1.62(1.67)$ & $1.01(0.30)$ \\
\hline HTT & $0.47(0.11)$ & $0.83(0.79)$ & $0.48 \quad(0.10)$ & $0.62(0.46)$ & $1.58(1.57)$ \\
\hline 咀嚼時間 & - & $7.79(3.86)$ & $11.19(4.52)$ & $17.91(7.19)$ & $7.97(4.82)$ \\
\hline $\begin{array}{l}\text { 咀嚼停止から舌骨挙上 } \\
\text { 開始までの時間 }\end{array}$ & - & $0.13(0.25)$ & $0.03 \quad(0.25)$ & $0.06(0.20)$ & $-0.06(0.18)$ \\
\hline
\end{tabular}

Mean（SD)。各条件下の嬿下位相時間の平均值とSD を示した。混合咀嚼以外では嚥下反射開始より 先に咀嚼停止が起こったが，混合咀嚼でのみ噯下反射開始が咀嚼停止に先行した。

Stage I + Process：(口腔内移送時間), PFAT : Postfaucial aggregation time（口腔咽頭上部領域通 過時間), VAT: Valleculae aggregation time (喉頭蓋谷領域通過時間), HTT: Hypopharyngeal transit time（下咽頭領域通過時間）

VAL-om については，液体命令とすべての咀嚼条 件（液体咀嚼を含む）との間に有意差を認めた。咀嚼 条件内では, 混合とその他の咀嚼条件とで有意差を認 めた。

HYP では, 液体命令と液体咀嚼, 混合との間で有 意差を認めた。また，混合はその他の全条件との間に 有意差を認めた。

\section{2. 嚥下反射開始を基準とした各嚥下位相時間の比 較（表 3, 図 3, 図 4)}

舌骨挙上開始をゼロとして各条件の與下位相の平均 時間を図 3 に示した。 以下に主な所見を列挙する.

咀嚼運動が停止してから舌骨挙上開始までの時間 は，液体，コンビーフ，クッキーでは 0.03 から 0.13 秒で有意差を認めなかったが，混合では舌骨挙上開始 が咀嚼停止より 0.06 秒早く生じていた。命令睘下に 比べ咀嚼 4 条件下では, 口腔から中咽頭までの各嚥下 


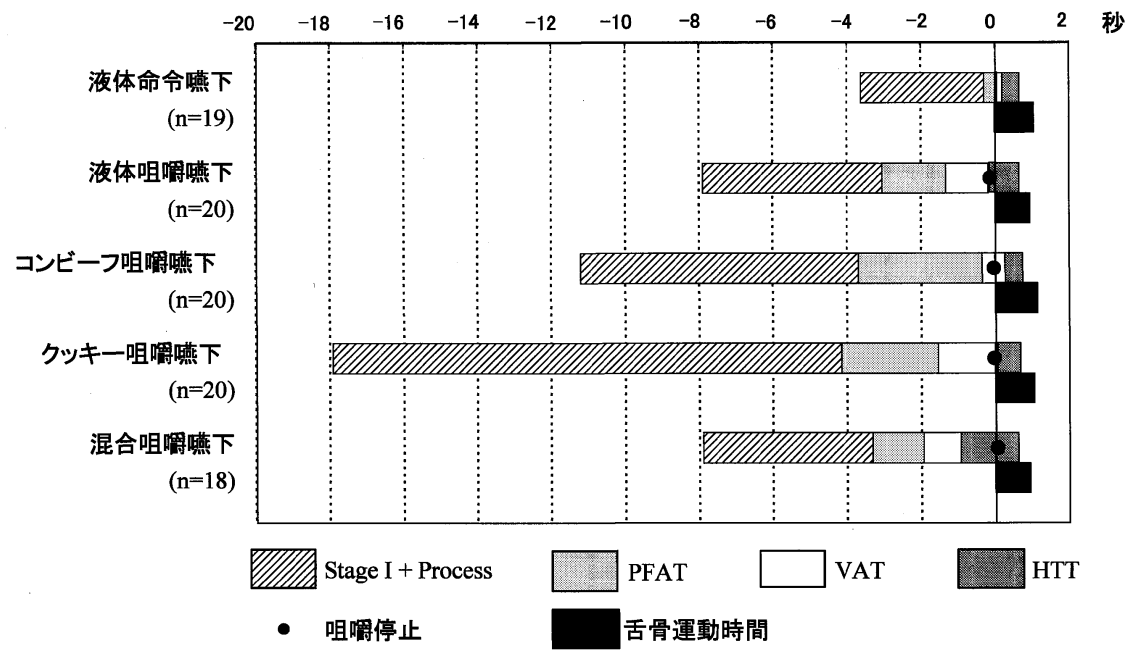

図 3 讌下位相時間

嚥下反射開始時点（=舌骨挙上開始時点）をゼロとして各条件の曣下位相の平均值を示した。咀嚼停止時点 をグラフ中の黒丸で示した，液体咀嚼と混合咀嚼で嚥下反射開始前に食塊が下咽頭に到達しており，とくに 混合咀嚼で食塊が下咽頭に達してから嬩下反射が始まるまでの時間が長い.
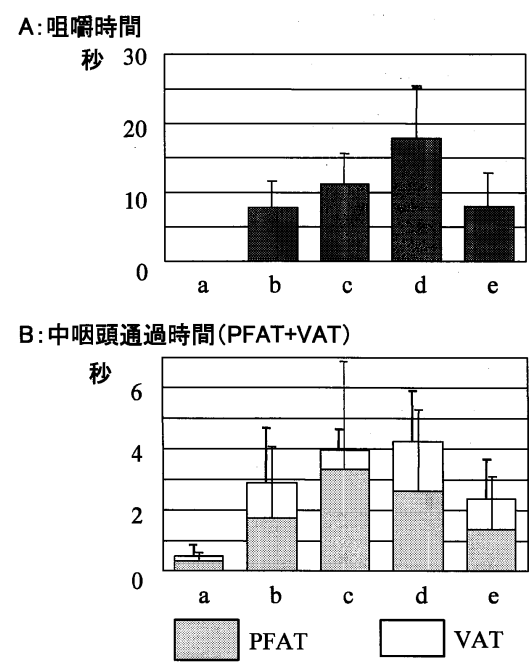

C: 下咽頭通過時間(HTT)

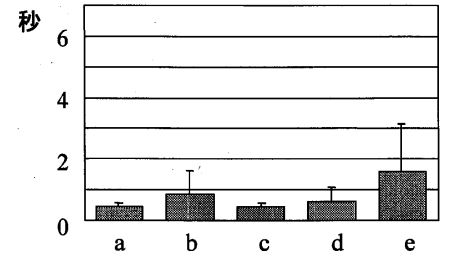

図 4 咀嚼時間と嶼下位相時間

A：咀嚼時間，B：中咽頭通過時間（PFAT+VAT）, C ：下咽頭通過時間 (HTT)。 $\mathrm{a}$ ：液体命令， b 液体 咀嚼, $c$ ：コンビーフ, d:クッキー, e : 混合. 食塊の性状によって咀嚼時間と中咽頭通過時間は同様の傾 向の変化を呈し, 2 者間で有意な相関を認めた $(r=0.439) . H T T$ は液体咀嚼と混合において著しく長か った $($ ANOVA $<0.01) . H T T$ と咀獣時間との相関は認めなかった.

位相時間（Stage I + Process, PFAT, VAT）が長か った（ANOVA, $p<0.01)$. 液体おょび混合物の咀 嚼負荷条件では HTT が他の条件に比べて有意に長か った（ANOVA, $p<0.01$ ).

咀嚼時間と各位相時間を図 4 に示す，咀嚼時間（図 $4 \mathrm{~A})$ はクッキーが最も長く 17.9 秒で, コンビーフ
11.2 秒, 混合 8.0 秒, 液体 7.8 秒であり, 食物の物 性，つまり，固さに関連していた。

食塊の中咽頭通過時間 (PFAT+VAT)（図 4 B) は クッキーで最も長く, コンビーフ, 液体咀嚼, 混合と 続き, ほほ咀嚼時間の順と同様の傾向を示し, 咀嚼時 間と中咽頭通過時間 (PFAT+VAT) との間には有意 
な相関を認めた（ $r=0.439 ） . \mathrm{HTT}$ (図 $4 \mathrm{C}$ ) は, 混 合 1.58 秒, 液体咀嚼 0.83 秒, クッキー 0.62 秒, コ ンビーフ 0.48 秒で, 咀嚼時間との関連は認めず, 液 体咀嚼および混合でのみ液体命令に比して長かった。

\section{考 察}

Palmer らは, 固形物の咀嚼嬩下を説明するプロセ スモデルを提案した5).このモデルの特徵は, 嚥下反 射前に咀嚼に伴って食塊が口峡から咽頭に送り込まれ る現象（Stage II transport）にある4,5).しかし，そ の際, Stage II transport を生み出す鍵となるのが, 固形物の嚥下という食塊の物性によるものなのか, あ るいは咀嚼という運動なのかという点は明らかでなか った. 今回の我々の検討（表 1)により, 液体命令に 比して, 液体咀嚼を含むすべての咀嚼嶼下条件で VAL-om が有意に高率であったことから, 咀嚼運動 の存在が Stage II transport を生み出し, 食塊の咽頭 進入の程度に食塊の物性が関与することが示唆され た。

\section{1. 食塊先端位置による検討}

Stage II transport の発生頻度には, 食物の形態に より差が見られた. 発生頻度は, Palmer らの実験で は明示されなかった点である.すなわち，ここで仮に UOP-omあるいはVAL-omをもって Stage II transport の発生と定義すると, それぞれ, 液体咀嚼 $55.0 \%, 45.0 \%$, コンビーフ $85.0 \%, 55.0 \%$, クッ キー $90.0 \%, 65.0 \%$, 混合 $100 \% ， 100 \%$ と咀嚼嚥下 条件下でもばらつきがあり, 特に, 混合を除く均一な 食物では $100 \%$ に生じるわけではなかった。このこと は, Stage II transportがヒトの咀嚼嶼下で常に生じ る,すなわち, hardwired な現象ではなく, 変動性を 有する現象であることを示唆した。また，詳細な検討 は後日の報告で行うが，この発生頻度は明らかな個人 差のある現象と思われた，以上は，咀嚼䠢下様式の多 様性を意味すると思われ，臨床的には，嶼下障害者に おいて Stage II transport を起こさない咀嚼様式の考 案など訓練への適用という観点からみて重要と考え た。一方, Stage II transportを評価する方法として 咀嚼嶼下を考えた場合, 混合で Stage II transport が $100 \%$ 出現したという結果から, 咀嚼負荷を検査法と して使用する際の信頼性を確保するために混合咀嚼負 荷が有用と思われた。ちなみに Stage II transport は 基本的には能動的過程と定義されているため, 厳密に
は漏れなどの受動的な食塊進行と区別する必要があ る.しかし，今回の検討は主に位置情報という結果か らの解析のため，そこまでの区別はできなかった。

さらに, 液体咀嚼, 混合では, 食塊が嚥下反射開始 前に下咽頭にまで達する現象が，その他の条件に比し て高率に見られた（液体咀嚼 $25 \%$ ，混合 $72 \%$ ）。この 嚥下反射前に食塊が口峡, 喉頭蓋谷を越えて下咽頭に 存在するという現象が健常者で高率に認められたとい う結果は, 誤魷防止という観点から見た場合重要な意 味を持つ.つまり, 健常者の場合, 嶼下反射前に食塊 が下咽頭まで達する例があっても誤嶼を生じることは まれであり(本検討では，1例にのみ誤器を認めた), 喉頭周囲の感覚を含む気道防御機構が誤嶼を防いでい ると考えられる。すなわち曣下障害患者における誤曣 のメカニズムとしては, 反射遅延という概念に加え て，喉頭閉鎖機能不全や呼吸と嚥下の協調不全の影響 が重要であると推測できた。従って, 従来からいわれ ている詋嚥防止のために「咽頭に食塊が進行すれば即 座に嚥下反射が生じることが重要」という考え方には 一定の修正が必要と思われた。この食塊の HYPへの 進行は, Palmer の実験では専ら固形物や半固形物を 用いていたため見落とされていた所見である.

また, HYPへの進行が液体を含む食物の咀嚼負荷 で高率であったことから，臙下反射前の喉頭蓋谷から 下咽頭（vertical portion）にかけての食塊の進行に は，重力による流れ込みが関与している可能性が高い と考えた。すなわち，固形物咀嚼嚥下において食塊の UOP (horizontal portion) やVAL (horizontal portion と vertical portionの移行部) への進行には舌運 動の能動的過程が重要であることが, すでに Palmer により，重力の影響を取り除いた系である「四つ這い 位を用いた実験」で示されたが7)，水分を含む食物の 場合, さらにこれに加えて, 重力による受動的過程が vertical portionである下咽頭への食塊進行を生み出 していると思われた.この発生機序については, 現 在, さらに, 四つ這い位実験による検討を予定してい る.

咀嚼嚥下における 4 条件において UOP-om と VAL-om の深達率は, 混合, 固形物（コンビーフ, クッキー), 液体咀嚼の順となっていた。咀嚼中の舌 には, 食塊を舌上に保持する動き, 歯と歯の間に食塊 を保持する動き, 食塊を口腔前方から舌根部へ送り込 むための squeeze back や食塊を咽頭に落とし込む 
tongue retractなどの 3 次元的な動きが観察され る ${ }^{8 \sim 10)}$.このような能動的な舌の動きと関連して食塊 の硬度, 付着性, 凝集性などの物的特性と重力が食塊 の咽頭深達度に影響を与えていると思われる。また， 下咽頭到達率は液体咀嚼で $25 \%$, 混合咀嚼で $72.2 \%$ であり, 液体を含む食塊の咀嚼であっても, 液体が一 律に下咽頭（HYP） へ到達する訳ではないことを意

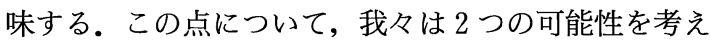
ている. 1 つは, 液体の咀嚼嶼下が不自然な課題であ り，咀嚼が十分に行われていないため食塊が十分送り 込まれなかった可能性である，もう 1 つは，混合では 食塊が均一ではないために, 咀嚼時に口峡部での舌と 口蓋とによる oropharyngeal seal が不完全になるた め口腔からの漏れが生じたという考え方である.

\section{2. 嚥下位相時間からの検討}

時間経過から見た場合，HTT が，液体咀嚼および 混合で長かった点も重要な所見である。咀嚼嶼下で は，咽頭に食塊が進入してもすぐには嚥下反射が起こ らず，食塊がある程度まとめられた後に嚥下反射運動 が生じていた。これは液体の命令臙下で用いられてき た「臙下反射開始前に食塊が口峡を越えて咽頭に達す る例は嶼下反射遅延という異常所見」とする考え方6) をそのまま咀獣嚥下へは適用できないことを意味し， 特有な口腔・喉頭・咽頭構造をもつヒトでは, その嚥 下動態を命令嬩下と咀嚼嬩下とで分けて考える必要性 を示唆するものである.

\section{1 嚥下反射開始時点の定義}

また，嚥下動態の位相時間の解析における基準点 （嚥下反射開始時点）の定義は，VF 側面像で「食塊 が口峡を越えた時点」あるいは「食塊が下䫟下縁を越 えた時点」など解剖学的指標に対する食塊の位置で決 められることが多く, プロセスモデルでも食塊が下咽 頭を通過する時間（HTT）が曣下反射の時間を反映 するとされた。しかし我々の結果で咀嚼条件により HTT が変動を示したこと, さらに, 食物の物性, つ まり, 固さに関連して PFAT, VAT が大きく変化し ていたことから解剖学的指標に対する食塊の位置から 求める時間（時刻）にはばらつきが大きく，計測の基 準点として適切ではないと思われた。一方，舌骨運動 時間にはばらつきが少なく, 舌骨運動開始時点を計測 の基準点として用いる方が合理的と考えた。

\section{2 咀嚼から嚥下への移行のタイミング}

さらに, 咀嚼嚥下では, 咀嚼停止一舌骨運動開始時
間は「咀嚼運動から嚥下運動へと運動が切り替わる過 程」を反映するといわれており ${ }^{11,12)}$, その変動の観察 により咀緭嬩下について一定の洞察が得られると思わ れた。通常は咀嚼一嚥下連関は安定した構造を有し, 咀嚼が停止してから嬩下反射が開始される．今回の混 合物を除いた条件での結果もそれを支持するものであ った，しかし，混合物の嬩下では，それが逆転し舌骨 挙上開始が咀嚼停止より 0.06 秒早かった。つまりこ れは, 口腔内に固形物を主とする食塊があり咀嚼が続 いている間に下咽頭へ液体を主とする食塊が大量に流 入した場合に，誤嚥を防ぐために緊急的な脳幹の嶼下 中枢を介する反射機構が発現し，嚥下反射が惹起され たものと考えた。この嚥下反射発現様式には，咽頭の 静的感覚入力以外にも, Pouderoux らの述べる食塊 の咽頭進入速度の影響や喉頭蓋谷の容量の影響を考慮 する必要があろう13).

\section{3. 咀嚼負荷嚥下法の有用性と今後の展望}

以上みてきたように，咀嚼嚥下は命令嚥下と大きく 異なっており, 咀嚼は嚥下前の食塊の咽頭深達度と嚥 下反射開始の両方に影響を与えていると考えた。咀嚼 に伴って舌が能動的に食塊を咽頭に送り込む Stage II transport の時期には気道と食物経路が同時に開存 する，鱮下障害者に当てはめた場合，論理的には誤嬩 の危険性が極めて大きい.また，水分を含んだ食物の 咀嚼負荷の場合, 下咽頭まで食塊が進行する例が高率 に存在し, 食物形態の差によって咀嚼負荷時の誤槱の 危険性が大きく異なる可能性が考えられる. 我々が臨 床において用いている摂食・噁下障害の重症度分類 は，重症度の高い順に，1）唾液誤嚥，2）食物誤嚥, 3）水分誤嚥，4）機会誤嚥，5）口腔問題，6）軽度問 題，7）問題なし，の 7 段階からなる ${ }^{14)}$.このうち, 「機会誤嚥」に該当する症例では，液体またはぺース トで評価する通常のVFでは誤嚥が検出されないが, 実際の食事場面でのむせや食後の喀痰の増加などの誤 嚥徴候を認める場合が含まれる。そして，このような 例の咀嚼嚥下で誤嚥を認める症例が存在することを予 備的検討で確認しており, 今後, 黇下障害軽症例にお ける負荷テストとして, 咀嚼嶼下負荷法の有用性を検 証する予定である。また咀嚼に伴う食物の物性変化 が，食塊の咽頭進入や嚥下反射惹起に影響を与えるこ とが予測され，今後の検討課題と考える.

振り返って「食事」という行為を考えると, 飲むこ と（drink）と食べること（eat）という 2 つの区別さ 
れる行動が存在する. 我々の日常において, 咀嚼嬩下 は決してまれな行動ではないのである.ここで $\lceil$ drink」にはヒト独特の 4 期連続モデルが適用でき, 「eat」にはプロセスモデルが適用されると整理でき る.こうして見ると, 従来の與下評価は「drink」中 心の評価であり, 今後, これまで以上に「eat」を意 識した評価を加える必要性を感じた。また，咀嚼と嚥 下の研究は歴史的にはそれぞれ歯科領域と耳鼻咽喉科 領域において別々に行われてきたといえるが，ヒトに おける咀嚼と嶼下の関連をその神経機構を含めて統合 的に再検討する必要があろう.

\section{ま と め}

咀嚼嚥下の評価法を確立するために，咀嚼嚥下の際 の與下反射開始時の食塊先端の深達度および䁵下反射 開始のタイミングを検討した。被験物に液体, コンビ ーフ，クッキー，コンビーフと液体の混合物を用い， 健常成人 10 名において, 自由咀嚼させた後に生じる 自由なタイミングでの嚥下, すなわち, 咀嚼嚥下を観 察した。また，液体の命令嚥下も記録した。舌骨運動 開始時点の食塊の到達位置を求め, 口腔内 $(\mathrm{OC})$, 口 腔咽頭上部領域以降 (UOP-om), 喉頭蓋谷領域以降 (VAL-om)，下咽頭領域（HYP）に区別し，各嚥下 条件で比較した。ささらに, 各嚥下位相の時間経過を求 め, 各嶼下条件で比較した。結果と考察は以下のよう にまとめられた。すなわち，

1）液体命令に比して, 全咀嚼条件でVAL-om が 有意に高率であり, stage II 発生には咀嚼が一義的条 件と思われた。

2）咀嚼嚥下時の stage II の発生率は, 食物条件で 異なり, 単一食物条件下では必ず認められる hardwired な現象ではなく, 変動性を有すると思われた。 一方, 混合条件では, $100 \%$ 発生し, 負荷法として適 切と思われた。

3）液体を含む咀嚼（液体咀嚼, 混合）では，その 他の条件に比して HYP が高率であり, 下咽頭通過時 間（HTT）が長かった。䁵下運動前に下咽頭にまで 食塊が進行するという結果は, 誤嚥防止機構を考える 上で極めて重要な所見と思われた。

4）各曣下位相時間は食物条件で異なり，特に，咀 嚼時間と中咽頭通過時間（PFAT+VAT）に相関が 見られた。一方, 舌骨運動時間は食物条件によるばら つきが少なく, 舌骨運動開始時点を計測の基点として
用いることが合理的と考えられた。また，咀嚼停止か ら舌骨挙上開始までの時間の変動性も少なかった.

5）咀嚼と器下の関連性を統合的に理解することが 更なる課題と考えた.

本研究の一部は, 平成 12,13 年度厚生科学研究補助金 「摄食・嶼下障害の治療・対応に関する統合的研究」によ った.

\section{文献}

1）才藤栄一, 木村彰男, 矢守 茂, 森ひろみ, 出江紳一, 千 野直一: 燕下障害のリハビリテーションにおける videofluorography の応用. リハ医学 $1986: 23: 121$ 124

2) Palmer JB, Kuhlemeier KV, Tippett DC, Lynch C: A protocol for the videofluorographic swallowing study. Dysphagia 1993; 8: 209-214

3) Ekberg O : Is it good to be spontaneous ? Dysphagia $1999 ; 14: 43$

4) Palmer JB: Integration of oral and pharyngeal bolus propulsion: a new model for the physiology of swallowing. Jpn J Dysphagia Rehabil 1997; 1: $15-30$

5) Hiiemae KM, Palmer JB : Food transport and bolus formation during complete feeding sequences on foods of different initial consistency. Dysphagia $1999 ; 14: 31-42$

6) Logemann JA : Evaluation and Treatment of Swallowing Disorders. College-Hill Press, San Diego, 1998

7) Palmer JB: Bolus aggregation in the oropharynx does not depend on gravity. Arch Phys Med Rehabil 1998; 79: 691-696

8) Abd-el-Malek $S$ : The part played by the tongue in mastication and deglutition. J Anat 1955; 89: 250254

9) Shawker T, Sonies B, Hall TE, Baum BF : Ultrasound analysis of tongue, hyoid and larynx during swallowing. Invest Radiol 1984; 19: 82-86

10) Palmer JB, Hiiemae KM, Liu J: Tongue-jaw linkages in human feeding: a preliminary videofluorographic study. Arch Oral Biol 1997; 42 : 429-441

11) Miller AJ : The Neuroscientific Principles of Swallowing and Dysphagia. Singular Pub. Group, San Diego, 1999

12) Lamkadem M, Zoungrana OR, Amri M, Car A, Roman C: Stimulation of the chewing area of the cerebral cortex induces inhibitory effects upon swallowing in sheep. Brain Res 1999; 832 : 97-111

13) Pouderoux P, Logemann JA, Kahrilas PJ : Pharyngeal swallowing elicited by fluid infusion: role of volition and valecular containment. Am J Phys 1996 ; 270 : G 347-354

14）馬場 尊, 才藤栄一: 摂食・嬩下障害に対するリハビ リテーションの適応. 臨床リハ $2000 ; 9$ : 857-863 